(c) American Dairy Science Association, 2002.

\title{
Effects of Dietary Supplementation of Rumen-Protected Conjugated Linoleic Acid in Dairy Cows during Established Lactation ${ }^{1}$
}

\author{
J. W. Perfield II, G. Bernal-Santos, ${ }^{2}$ T. R. Overton, and D. E. Bauman \\ Department of Animal Science \\ Cornell University, Ithaca, NY 14853
}

\begin{abstract}
Short-term studies ( $<5 \mathrm{~d})$ involving abomasal infusion of a mixture of CLA isomers or pure trans-10, cis-12 CLA have demonstrated that supplements of conjugated linoleic acids (CLA) reduce milk fat synthesis during established lactation in dairy cows. Our objective was to assess longer term effects of supplementation during established lactation using a dietary supplement of rumen-protected CLA. Thirty Holstein cows were blocked by parity and received a dietary fat supplement of either Ca-salts of palm oil fatty acids (control) or a mixture of Ca-salts of palm oil fatty acids plus Ca-salts of CLA (CLA treatment). Supplements provided about $90 \mathrm{~g} / \mathrm{d}$ of fatty acids and were topdressed on the TMR. The CLA supplement provided $30.4 \mathrm{~g} / \mathrm{d}$ of CLA in which the predominant isomers were: trans-8, cis-10 (9.2\%), cis-9, trans-11 (25.1\%), trans-10, cis-12 (28.9\%), and cis-11, trans-13 (16.1\%). All cows were pregnant; treatments were initiated on $\mathrm{d} 79$ of pregnancy ( $\sim 200 \mathrm{~d}$ prepartum) and continued for $140 \mathrm{~d}$ until dry off. Twenty-three cows completed the study; those receiving CLA supplement had a lower milk fat test (2.90 versus $3.80 \%$ ) and a $23 \%$ reduction in milk fat yield (927 versus $1201 \mathrm{~g} / \mathrm{d})$. Intake of DM, milk yield, and the yield and content of true protein and lactose in milk were unaffected by treatment. Milk fat analysis indicated that the CLA supplement reduced the secretion of fatty acids of all chain lengths. However, effects were proportionally greater on short and medium chain fatty acids, thereby causing a shift in the milk fatty acid composition to a greater content of longer-chain fatty acids. Changes in body weight gain, body condition score, and net energy balance were not significant and imply no differences in cows fed the
\end{abstract}

Received January 23, 2002

Accepted April 2, 2002.

Corresponding author: D. E. Bauman; e-mail: deb6@cornell.edu.

${ }^{1}$ Supported in part by Bioproducts Inc. (Fairlawn, OH), Agribrands Purina Canada Inc. (Woodstock, Ontario), BASF AG. (Ludwigshafen, Germany), and Cornell Agricultural Experiment Station.

${ }^{2}$ Present address: Universidad Autónoma de Querétaro, Facultad de Ciencias Naturales, Medicina Veterinaria y Zootecnia, Querétaro, Qro. CP 76000, MEXICO.
CLA supplement in replenishment of body reserves in late lactation. Likewise, maintenance of pregnancy, gestation length, and calf birth weight were unaffected by treatment. Overall, feeding a dietary supplement of rumen-protected CLA to pregnant cows over the last 140 $\mathrm{d}$ of the lactation cycle resulted in a marked reduction in milk fat content and yield, and a shift in milk fatty acid composition, but other milk components, DMI, maintenance of pregnancy, and cow well-being were unaffected.

(Key words: conjugated linoleic acid, CLA, milk fat, lactation, cow)

Abbreviation key: CLA = conjugated linoleic acid, $\mathbf{N C N}=$ noncasein nitrogen, $\mathbf{N E B}=$ net energy balance, $\mathbf{T N}=$ total nitrogen, $\mathbf{T P}=$ true protein

\section{INTRODUCTION}

Conjugated linoleic acid (CLA) supplementation has been shown to reduce milk fat content in lactating cows (Loor and Herbein, 1998; Chouinard et al., 1999a, 1999b), pigs (Harrell et al., 2000; Poulos et al., 2000), and nursing women (Masters et al., 1999). Comparisons of pure CLA isomers infused into the abomasum demonstrated that trans-10, cis-12 inhibited milk fat synthesis, whereas the major CLA isomer in milk fat, cis-9, trans11, had no effect (Baumgard et al., 2000). Based on comparisons of different CLA mixtures, it has been suggested that the trans- 8 , cis-10 isomer may also cause a reduction of milk fat yield (Bauman et al., 2001).

Trans-10, cis-12 CLA can be produced by rumen biohydrogenation under certain dietary circumstances (Griinari and Bauman, 1999). Consistent with the biohydrogenation theory of milk fat depression, there is an inverse relationship between milk fat content of trans-10, cis-12 CLA and milk fat yield (Bauman and Griinari, 2001). Economics usually favor milk fat on commercial dairy farms, but there are some scenarios when reduced output of milk fat could be advantageous. These include markets where producers are regulated by a quota system based upon milk fat and situations where animals cannot consume sufficient energy to meet requirements. 
Examples of the latter could include the transition period and early lactation, or adverse environmental effects such as heat stress and poor weather conditions for sufficient growth of forage in pasture-based systems.

Most investigations of the effect of CLA on milk fat in dairy cows have lasted only a few days and used abomasal infusion as a convenient experimental method to bypass rumen fermentation. Three recent abstracts report studies using early lactation animals in which the diet was supplemented with rumen-protected CLA. Two of the studies were less than 11 wk in duration (Giesy et al., 1999; Medeiros et al., 2000), while the third covered the first 20-wk of lactation (Bernal-Santos et al., 2001). There have been no investigations of the effects of supplementing rumen-protected CLA during the later stages of lactation. Effects on replenishment of body reserves during the later stages of the lactation cycle would be of interest because CLA supplementation has been shown to reduce body fat accretion in growing animals (Dugan et al., 1997; DeLany et al., 1999; Ostrowska et al., 1999; Azain et al., 2000). Likewise, maintenance of pregnancy would be of interest in CLA-treated cows because birds fed dietary supplements of CLA produced eggs with high embryonic mortality and reduced hatchability (Aydin et al., 1999a, 1999b). Thus, our objective was to assess the effects of CLA supplementation during established lactation on production parameters, replenishment of body reserves, and maintenance of pregnancy, as well as the overall health of the animal.

\section{MATERIALS AND METHODS}

\section{Animals, Treatments, and Sampling}

The Cornell University Institutional Animal Care and Use Committee approved all procedures involving animals. Over a 10-wk interval, 30 pregnant, lactating Holstein cows were selected, blocked by parity into two treatment groups, and housed in tie stalls at the Cornell University Dairy Teaching and Research facility. Cows started treatment at d 79 of pregnancy ( $200 \mathrm{~d}$ prior to calving; $227 \pm 69$ DIM) and continued for $140 \mathrm{~d}$ until dry off. Each treatment group received a calcium protected fat supplement that was topdressed once daily on their TMR. Rumen-protected fat supplements were 116 $\mathrm{g} / \mathrm{d}$ of Ca-salts of palm oil fatty acids (EnerGII; Bioproducts Inc. Fairlawn, $\mathrm{OH}$ ) for the control treatment and $126 \mathrm{~g} / \mathrm{d}$ of a mixture of Ca-salts of palm oil fatty acids plus Ca-salts of CLA (Agribrands Purina Canada Inc., Woodstock, Ontario) for the CLA treatment group. Supplements provided about $90 \mathrm{~g} / \mathrm{d}$ of fatty acids with the composition (Table 1). The CLA supplement provided $30.4 \mathrm{~g} / \mathrm{d}$ of CLA, and the four predominant CLA isomers were: trans-8, cis-10 (9.2\%), cis-9, trans-11 (25.1\%), trans-10, cis-12 (28.9\%), and cis-11, trans-13 (16.1\%).
Table 1. Fatty acid composition of fat supplements. ${ }^{1}$

\begin{tabular}{lcr}
\hline Fatty acid, $\mathrm{g} / 100 \mathrm{~g}$ & Control & CLA \\
\hline $16: 0$ & 44.9 & 21.2 \\
18:0 0 & 4.3 & 4.4 \\
18: 1 cis- 9 & 40.1 & 30.5 \\
18:2 cis- 9, cis-12 & 8.9 & 8.0 \\
Conjugated linoleic acid & & \\
18:2 trans-8, cis-10 & & 8.1 \\
18:2 cis-9, trans-11 & & 9.8 \\
18:2 trans-10, cis-12 & & 5.5 \\
18:2 cis-11, trans-13 & & 7.1 \\
Other CLA & 1.8 & 1.9 \\
Other & & \\
\hline
\end{tabular}

${ }^{1}$ Cows received a dietary fat supplement consisting of Ca-salts of palm oil fatty acids (control treatment) or Ca-salts of a mixture of conjugated linoleic acid isomers plus palm oil fatty acids (CLA treatment). Both treatments provided about $90 \mathrm{~g} / \mathrm{d}$ of fatty acids.

Cows were fed a TMR that was formulated using the Cornell Net Carbohydrate and Protein System (Fox et al., 1992) to meet or exceed predicted requirements for energy, protein, minerals and vitamins (NRC, 2001). Corn silage was the major forage component and ground shelled corn the primary concentrate (Table 2). Feeds were sampled weekly throughout the experiment, and $\mathrm{DM}$ content was determined by drying the feed at $110^{\circ} \mathrm{C}$ for $18 \mathrm{~h}$. The diet composition was adjusted weekly based on changes in the DM content of feed components. Feed samples were composited at 4-wk intervals and analyzed by wet chemistry methods for $\mathrm{CP}, \mathrm{ADF}, \mathrm{NDF}$, and minerals (Dairy One, Ithaca, NY). Cows were fed ad libitum, with fresh feed provided after each morning milking. Orts were weighed and recorded daily. Water was available at all times.

Table 2. Ingredient and chemical composition of diet.

\begin{tabular}{lc}
\hline Composition & Concentration \\
\hline Ingredient, \% of DM & \\
Alfalfa hay & 8.6 \\
Corn silage & 30.9 \\
Hay crop silage & 15.5 \\
Ground shelled corn & 24.6 \\
Whole cottonseed & 5.6 \\
Soybean meal (54\% CP) & 3.7 \\
Expeller soybean meal & 7.7 \\
Sodium bicarbonate & 0.5 \\
Vitamin and mineral mix 1 & 2.8 \\
Chemical analysis, \% of DM & \\
CP & 16.4 \\
NDF & 34.3 \\
ADF & 22.0 \\
NFC & 41.7 \\
EE & 4.7 \\
NE, Mcal/kg DM & 1.62 \\
\hline
\end{tabular}

${ }^{1}$ Contained $20.0 \% \mathrm{Cl}, 18.0 \% \mathrm{Na}, 12.0 \% \mathrm{Ca}, 8.0 \% \mathrm{~S}, 7.5 \% \mathrm{mg}, 1.0 \%$ $\mathrm{K}, 0.48 \% \mathrm{Zn}, 0.40 \% \mathrm{Mn}, 0.29 \% \mathrm{Fe}, 0.07 \% \mathrm{Cu}, 0.01 \% \mathrm{P}, 0.006 \% \mathrm{Co}$, $550 \mathrm{IU} / \mathrm{g}$ of vitamin A, $132 \mathrm{IU} / \mathrm{g}$ of vitamin D, $2970 \mathrm{IU} / \mathrm{g}$ of vitamin E.

${ }^{2} 100-((\mathrm{NDF}-\mathrm{NDICP})+\mathrm{CP}+\mathrm{Ash}+$ Fat $)$. 
Cows were milked 3 times per $\mathrm{d}$, and yields were recorded at each milking. Beginning $1 \mathrm{w}$ prior to treatment and continuing through the 20 -wk treatment period, milk samples were collected from each milking on $1 \mathrm{~d} /$ $\mathrm{w}$ and composited. Samples were stored at $4^{\circ} \mathrm{C}$ with a preservative (bronopol tablet; D\&F Control System, San Ramon, CA) until analyzed for fat, protein, lactose, and somatic cell count using infrared analysis (Dairy One). Additional milk samples were taken $1 \mathrm{w}$ before treatment and on wk $2,4,8,12,16$, and 20 ; these samples were stored at $-20^{\circ} \mathrm{C}$ without preservative until analyzed for fatty acid and protein composition.

Blood samples were collected on $1 \mathrm{~d} / \mathrm{w}$ beginning the week prior to treatment and continuing on wk $1,2,3$, $4,8,12,16$, and 20 . Blood was collected via venipuncture from the coccygeal vessels over the $30 \mathrm{~min}$ interval following the morning milking and prior to providing fresh feed. Sodium heparin (100 U/ml of blood) was used to prevent coagulation. Plasma was harvested following centrifugation $\left(2,800 \times \mathrm{g}, 15 \mathrm{~min}\right.$ at $\left.4^{\circ} \mathrm{C}\right)$ and stored at $-20^{\circ} \mathrm{C}$ until analyses for blood metabolites.

Body weights and body condition scores of each animal were recorded $1 \mathrm{~d} / \mathrm{w}$ throughout the study. Cows were body scored on a five-point system (Wildman et al., 1982) by two individuals and the average of these two scores was the assigned value. Daily observations and general health records were recorded throughout the study. Cows were also observed through the dry period, with calf sex and birth weight recorded at the subsequent parturition.

\section{Fatty Acid Analysis}

Milk fat was extracted using the method of Hara and Radin (1978) and fatty acid methyl esters were prepared by base-catalyzed transmethylation according to Christie (1982) with modifications by Chouinard et al. (1999a). Fatty acids in the rumen-protected supplements were methylated using $1 \%$ sulfuric acid in methanol as described by Christie (1989). Fatty acid methyl esters were quantified using a gas chromatograph (GCD system HP 6890+; Hewlett Packard, Avondale, PA) equipped with a SP-2560 fused silica capillary column $(100 \mathrm{~m} \times 0.25$ $\mathrm{mm}$ (i.d.) with 0.2- $\mu \mathrm{m}$ film thickness; Supelco, Bellefonte, $\mathrm{PA})$. The oven temperature was initially $80^{\circ} \mathrm{C}$, then ramped at $2^{\circ} \mathrm{C} / \mathrm{min}$ to $190^{\circ} \mathrm{C}$ and maintained for $15 \mathrm{~min}$. Inlet and detector temperatures were $250^{\circ} \mathrm{C}$ and the split ratio was 100:1. The hydrogen carrier gas flow rate was $1 \mathrm{ml} / \mathrm{min}$, hydrogen flow to the detector was $25 \mathrm{ml} /$ min, airflow was $400 \mathrm{ml} / \mathrm{min}$, and the flow of nitrogen make-up gas was $45 \mathrm{ml} / \mathrm{min}$. Fatty acid peaks were identified using pure methyl ester standards (Nu-Chek Prep, Elysian, MN). Additional standards for CLA isomers were obtained from Natural Lipids Ltd AS (Hovdebygda,
Norway). A butter oil reference standard (CRM 164; Commission of the European Community Bureau of References, Brussels, Belgium) was used to determine recoveries and correction factors for individual fatty acids.

\section{Milk Protein Analysis}

Total $\mathrm{N}$ (TN) and $\mathrm{N}$ fractions of milk were determined using macro-Kjeldahl techniques (AOCS, 2000). Milk NPN consisted of $\mathrm{N}$ that was soluble in $12 \%$ trichloroacetic acid. Noncasein N (NCN) was determined by precipitating casein at $\mathrm{pH} 4.6$ and filtering, leaving the filtrate for $\mathrm{N}$ analysis. From these milk $\mathrm{N}$ fractions, the following were calculated: $\mathrm{CP}$ equaled $(\mathrm{TN} \times 6.38)$; true protein (TP) equaled $(\mathrm{TN}-\mathrm{NPN}) \times 6.38$; casein protein equaled $(\mathrm{TN}-\mathrm{NCN}) \times 6.38$; and whey protein equaled $(\mathrm{NCN}-$ NPN) $\times 6.38$. Milk NCN and NPN were also converted to protein equivalents by multiplying by 6.38 to allow comparison with other protein fractions.

\section{Blood Metabolite Analysis}

Plasma glucose was determined by enzymatic analysis using a commercial kit (kit 510-A; Sigma Chemical, St. Louis, MO). Plasma concentrations of NEFA were analyzed by enzymatic analysis (NEFA-C; WAKO Pure Chemical Industries, Osaka, Japan). Plasma concentrations of BHBA were quantified using a commercial kit (kit 310-UV; Sigma Chemical). All analysis was done using a Versa ${ }_{\max }$ tunable microplate reader (Molecular Devices, Sunnyvale, CA). Inter-assay variation was maintained at $<5 \%$.

\section{Statistical Analysis}

Pretreatment values for each variable measured were used for covariate adjustment. Daily intake and milk yield values were reduced to weekly means before data analysis. Analysis of variance was conducted using the General Linear Models procedure of SAS (1998) for a completely randomized design with repeated measures. The model contained the effects of treatment, week of treatment, cow within treatment and the interaction of treatment by week. The overall effect of treatment was tested using cow within treatment as the error term. Least squares means are reported throughout, and significance was declared at $P<0.05$.

\section{RESULTS AND DISCUSSION}

All animals completed the first 10 -wk of the treatment period and their performance data are presented in Table 3. Supplementation with CLA decreased milk fat content and milk fat yield by 23 and 18\%, respectively. 
Table 3. Lactational performance over the first 10 -wk of treatment.

\begin{tabular}{lcccc}
\hline & \multicolumn{2}{c}{ Treatment $^{1}$} & & \\
\cline { 2 - 3 } Variable & Control & CLA & SEM & $P$ \\
\hline Cows, n & 15 & 15 & & \\
DMI, kg/d & 23.4 & 23.1 & 0.4 & 0.68 \\
Milk yield, kg/d & 34.5 & 35.9 & 0.9 & 0.25 \\
Milk fat & & & & \\
$\quad \%$ & 3.64 & 2.82 & 0.08 & $<0.001$ \\
$\quad$ Yield, g/d & 1235 & 1009 & 40 & $<0.001$ \\
Milk protein & & & & \\
$\quad \%$ & 3.03 & 3.01 & 0.04 & 0.70 \\
$\quad$ Yield, g/d & 1031 & 1079 & 28 & 0.23 \\
Milk lactose & & & & \\
$\quad \%$ & 4.72 & 4.69 & 0.03 & 0.56 \\
$\quad$ Yield, g/d & 1622 & 1688 & 46 & 0.32 \\
\hline
\end{tabular}

${ }^{1}$ Cows received a dietary fat supplement consisting of Ca-salts of palm oil fatty acids (control treatment) or Ca-salts of a mixture of conjugated linoleic acid isomers plus palm oil fatty acids (CLA treatment).

However, DMI, milk yield, and content and yield of milk protein and milk lactose were unaffected by treatment. A total of 23 cows completed the full 20 -wk of treatment. Two of the seven cows that did not complete the study were removed due to health (displaced abomasum) or physical injury (stifle injury), and the remaining five dried off early. Animals were assigned to the study based on stage of pregnancy rather than stage of lactation, and the animals that dried off early averaged 400 DIM. Performance results over the full 20 -wk for the 23 cows that completed the study (Table 4) were virtually identical to those for all cows over the first 10-wk of treatment (Table 3). Subsequent data presentation describes the 23 animals that completed the study.

Over the treatment period, CLA supplementation caused a 23 and $24 \%$ reduction in milk fat content and yield, respectively (Table 4). Studies involving pure CLA isomers have demonstrated that abomasal infusion of $10 \mathrm{~g}$ of trans-10, cis-12 reduced milk fat synthesis by $44 \%$, but infusion of the same amount of cis-9, trans-11 CLA had no effect (Baumgard et al., 2000). There was a curvilinear relationship between the dose of trans10, cis-12 CLA and milk fat yield, with the maximum reduction in milk fat yield approximately 50\% (Baumgard et al., 2001; Peterson et al., 2002). In contrast to milk fat, the yield of milk protein and milk lactose were unchanged (Table 4), and the temporal pattern of the decline in milk yield was nearly identical between treatment groups (Figure 1). The lack of effects of CLA on the yield of milk and milk protein are consistent with other investigations using cows in established lactation (Chouinard et al., 1999a; 1999b; Baumgard et al., 2000, 2001). However, all of the previous studies of established lactation have been short-term (up to $5 \mathrm{~d}$ ) involving abomasal infusion of the CLA.
Table 4. Performance parameters over the 20 -wk treatment period.

\begin{tabular}{|c|c|c|c|c|}
\hline \multirow[b]{2}{*}{ Variable } & \multicolumn{2}{|c|}{ Treatment $^{1}$} & \multirow[b]{2}{*}{ SEM } & \multirow[b]{2}{*}{$P$} \\
\hline & Control & CLA & & \\
\hline Cows, $\mathrm{n}$ & 12 & 11 & & \\
\hline DMI, kg/d & 22.8 & 22.6 & 0.5 & 0.78 \\
\hline Milk yield, $\mathrm{kg} / \mathrm{d}$ & 30.4 & 30.8 & 1.3 & 0.85 \\
\hline \multicolumn{5}{|l|}{ Milk fat } \\
\hline$\%$ & 3.80 & 2.90 & 0.06 & $<0.001$ \\
\hline Yield, g/d & 1201 & 927 & 35 & $<0.001$ \\
\hline \multicolumn{5}{|l|}{ Milk protein } \\
\hline$\%$ & 3.13 & 3.16 & 0.04 & 0.61 \\
\hline $\begin{array}{l}\text { Yield, g/d } \\
\text { Milk lactose }\end{array}$ & 992 & 1004 & 26 & 0.73 \\
\hline$\%$ & 4.74 & 4.72 & 0.03 & 0.63 \\
\hline Yield, g/d & 1529 & 1522 & 45 & 0.90 \\
\hline $\mathrm{SCC}, \times 1000$ & 223 & 255 & 33 & 0.49 \\
\hline $3.5 \% \mathrm{FCM}, \mathrm{kg} / \mathrm{d}$ & 32.8 & 28.3 & 0.88 & 0.001 \\
\hline Body weight, ${ }^{2} \mathrm{~kg}$ & 655 & 652 & 6 & 0.70 \\
\hline Body condition score ${ }^{3}$ & 3.4 & 3.4 & 0.1 & 0.72 \\
\hline Net energy balance, ${ }^{4} \mathrm{Mcal} / \mathrm{d}$ & 4.6 & 5.8 & 1.3 & 0.53 \\
\hline
\end{tabular}

${ }^{1}$ Cows received a dietary fat supplement consisting of Ca-salts of palm oil fatty acids (control treatment) or Ca-salts of a mixture of conjugated linoleic acid isomers plus palm oil fatty acids (CLA treatment).

${ }^{2}$ Cows were weighed $1 \mathrm{~d}$ each wk throughout the study.

${ }^{3}$ Cows were scored (five-point scale) by two individuals $1 \mathrm{~d}$ each wk through the study and values averaged.

${ }^{4}$ Calculated based on NRC (2001). For wk 1-16 the formula was: $(\mathrm{DMI} \times \mathrm{NEL}$ diet $)-\left(\left(0.08 \times \mathrm{BW}^{.75}\right)+((0.0929 \times\right.$ milk fat $\%+0.0563$ $\times$ milk protein $\%+0.0395 \times$ milk lactose $\%) \times$ MY). During wk $17-$ 20 the formula was adjusted to account for the energy requirements for gestation as follows: $\left(\mathrm{DMI} \times \mathrm{NE}_{\mathrm{L}}\right.$ diet $)-\left(\left(\left(0.08 \times \mathrm{BW}^{.75}\right)+((0.0929\right.\right.$ $\times$ milk fat $\%+0.0563 \times$ milk protein $\%+0.0395 \times$ milk lactose $\%) \times$ $\mathrm{MY})+([(0.00318 \times$ days pregnant -0.0352$) \times($ calf body weight $/ 45)] /$ $0.218)$.

Research with cows in early lactation has demonstrated that the reduction in milk fat yield which occurs with CLA supplementation is accompanied by an increase in milk and milk protein yield (Giesy et al., 1999; Medeiros et al., 2000; Bernal-Santos et al., 2001). In

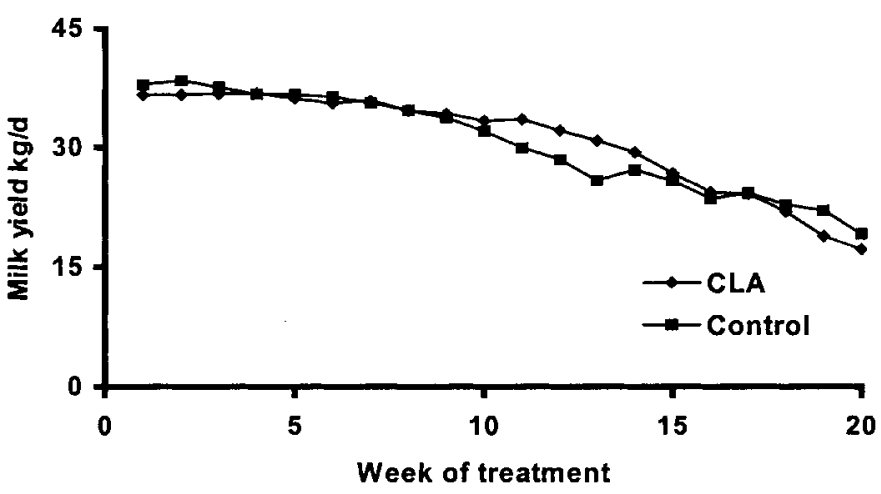

Figure 1. Temporal pattern of milk yield for cows fed a rumenprotected fat supplement with or without conjugated linoleic acid (CLA). Values are means, $\mathrm{n}=12$ for control and 11 for CLA treatments; SEM averaged $1.3 \mathrm{~kg} / \mathrm{d}$. 

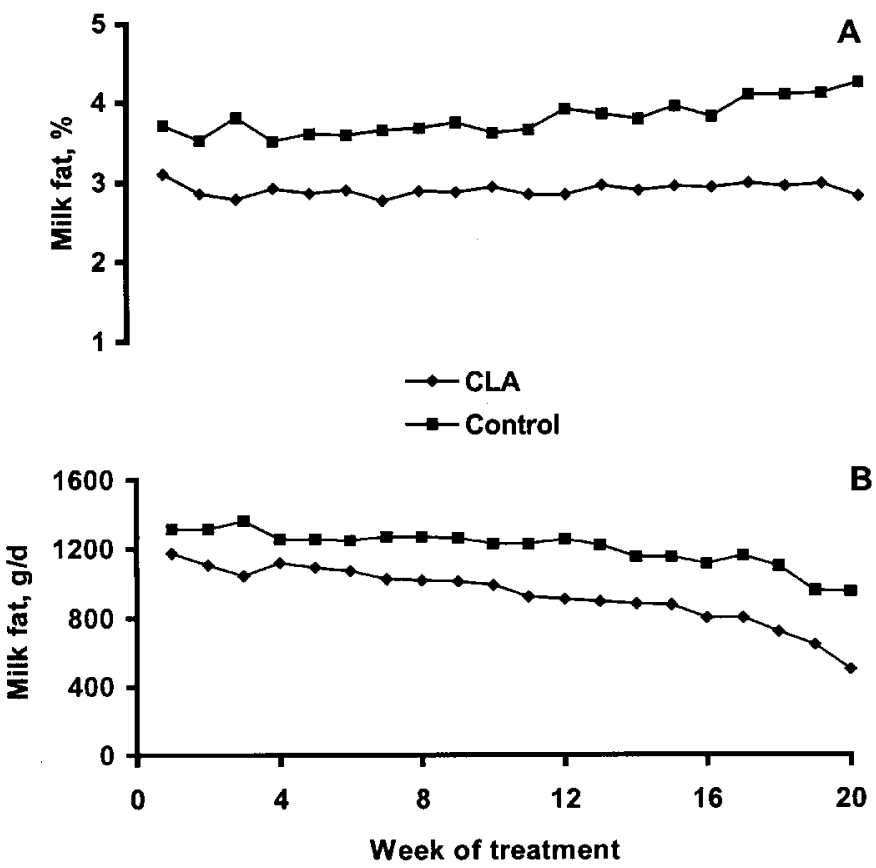

Figure 2. Temporal pattern of milk fat content (A) and milk fat yield (B) for cows fed a rumen-protected fat supplement with or without conjugated linoleic acid (CLA). Values are means, $\mathrm{n}=12$ for control and 11 for CLA treatments; SEM averaged 0.1 for milk fat percentage and $35 \mathrm{~g} / \mathrm{d}$ for milk fat yield.

those cases, cows were at a stage in the lactation cycle where intake generally was less than requirements and the reduction in milk fat would allow energy to be repartitioned for synthesis of milk protein and milk lactose. Cows in the present study were in positive energy balance, and the CLA supplement had no effect on milk or milk protein yield. Thus, the decrease in milk fat resulted in a decrease in $3.5 \% \mathrm{FCM}$ for the group receiving the CLA supplement (Table 4).

The decrease in milk fat yield in the CLA-supplemented group had occurred by the first sampling at the end of the first week of treatment and remained consistent throughout the 20-wk treatment period (Figure 2). The reduction in fat yield resulted from a decrease in the secretion of all milk fatty acids (Table 5). However, the reduction in the yield of the short and medium chain fatty acids $\left(<\mathrm{C}_{16}\right)$ was proportionally greater, causing a shift so that milk fat of cows receiving CLA had a greater content of long chain fatty acids ( $\geq$ C18) (Table 6). This shift in milk fatty acid composition is similar to that reported in short-term studies involving abomasal infusion of a similar mixture of CLA isomers (Loor and Herbein, 1998; Chouinard et al., 1999a, 1999b) or pure trans10, cis-12 CLA (Baumgard et al., 2000). Abomasal infusion studies with the trans-10, cis-12 CLA isomer have also demonstrated that the magnitude of the shift in the
Table 5. Yield of fatty acids in milk fat from cows receiving rumenprotected fat supplements.

\begin{tabular}{|c|c|c|c|c|}
\hline \multirow[b]{2}{*}{ Fatty acid, g/d } & \multicolumn{2}{|c|}{ Treatment $^{1,2}$} & \multirow[b]{2}{*}{ SEM } & \multirow[b]{2}{*}{$P$} \\
\hline & Control & CLA & & \\
\hline $4: 0$ & 50.67 & 35.58 & 2.12 & $<0.001$ \\
\hline $6: 0$ & 26.47 & 16.35 & 1.01 & $<0.001$ \\
\hline $8: 0$ & 14.41 & 8.76 & 0.53 & $<0.001$ \\
\hline $10: 0$ & 30.46 & 19.94 & 1.21 & $<0.001$ \\
\hline $12: 0$ & 34.95 & 24.25 & 1.16 & $<0.001$ \\
\hline $14: 0$ & 120.24 & 90.99 & 3.73 & $<0.001$ \\
\hline $14: 1$ & 10.14 & 8.95 & 0.48 & 0.09 \\
\hline $15: 0$ & 10.03 & 7.62 & 0.34 & $<0.001$ \\
\hline $16: 0$ & 337.45 & 235.65 & 11.82 & $<0.001$ \\
\hline $16: 1$ & 16.03 & 13.42 & 0.64 & $<0.01$ \\
\hline $17: 0$ & 7.21 & 8.70 & 2.84 & 0.71 \\
\hline 18:0 & 142.86 & 108.01 & 5.77 & $<0.001$ \\
\hline $18: 1$ trans -4 & 0.35 & 0.25 & 0.02 & $<0.001$ \\
\hline $18: 1$ trans -5 & 0.31 & 0.26 & 0.02 & 0.03 \\
\hline $18: 1$ trans $6-8$ & 4.81 & 4.29 & 0.18 & 0.05 \\
\hline $18: 1$ trans -9 & 3.78 & 3.26 & 0.11 & 0.01 \\
\hline $18: 1$ trans -10 & 6.79 & 6.19 & 0.27 & 0.12 \\
\hline 18:1 trans -11 & 13.17 & 9.62 & 0.42 & $<0.001$ \\
\hline 18:1 trans -12 & 14.77 & 7.12 & 3.94 & 0.18 \\
\hline $18: 1$ cis -9 & 260.87 & 229.85 & 8.76 & 0.02 \\
\hline $18: 2$ cis -9, cis -12 & 36.32 & 32.32 & 1.66 & 0.10 \\
\hline $18: 2$ cis -9, trans -11 & 5.31 & 4.53 & 0.19 & 0.007 \\
\hline $18: 2$ trans -10, cis -12 & $<0.01$ & 0.31 & 0.02 & $<0.001$ \\
\hline $18: 3$ & 5.14 & 4.40 & 0.21 & 0.02 \\
\hline $20: 0$ & 1.10 & 0.82 & 0.04 & $<0.001$ \\
\hline Other & 40.93 & 29.92 & 3.08 & 0.02 \\
\hline \multicolumn{5}{|l|}{ Summation } \\
\hline$<\mathrm{C} 16$ & 297.65 & 212.32 & 9.67 & $<0.001$ \\
\hline C16 \& C16:1 & 353.16 & 249.37 & 12.23 & $<0.001$ \\
\hline$>\mathrm{C} 16$ & 502.71 & 419.96 & 15.41 & 0.001 \\
\hline
\end{tabular}

${ }^{1}$ Cows received a dietary fat supplement consisting of Ca-salts of palm oil fatty acids (control treatment) or Ca-salts of a mixture of conjugated linoleic acid isomers plus palm oil fatty acids (CLA treatment).

${ }^{2}$ There was no treatment $\times$ time interaction, and values represent average of milk samples obtained at treatment week $2,4,8,12,16$, and 20 .

milk fatty acid composition and the reduction in milk fat yield increases as the dose of this CLA isomer increases (Baumgard et al., 2001). The rumen-protected CLA supplement was composed of four CLA isomers, and cows receiving the supplement had an increase in both yield and concentration of trans-10, cis-12 CLA in milk fat (Tables 5 and 6). The content of cis-9, trans-11 CLA, another CLA isomer in the supplement, also was increased in milk fat (Table 6); the, yield of this isomer was reduced by treatment (Table 5), however, because of the overall reduction in milk fat yield. The remaining two isomers in the supplement (trans-8, cis-10 CLA and cis-11, trans-13 CLA) were not detectable with the analytical system that was used.

In the present study, the Ca-salts of CLA provided 8.8 $\mathrm{g} / \mathrm{d}$ of trans-10, cis-12 CLA in the diet, and on average $0.3 \mathrm{~g} / \mathrm{d}$ were secreted in the milk fat. Thus, transfer efficiency to milk fat averaged $3.4 \pm 0.4 \%$ (mean \pm SD) and was similar at each of the sampling periods through- 
Table 6. Fatty acid composition of milk fat from cows receiving rumen-protected fat supplements.

\begin{tabular}{|c|c|c|c|c|}
\hline \multirow[b]{2}{*}{ Fatty acid, \% } & \multicolumn{2}{|c|}{ Treatment ${ }^{1,2}$} & \multirow[b]{2}{*}{ SEM } & \multirow[b]{2}{*}{$P$} \\
\hline & Control & CLA & & \\
\hline $4: 0$ & 4.32 & 3.83 & 0.20 & 0.02 \\
\hline $6: 0$ & 2.26 & 1.80 & 0.08 & $<0.001$ \\
\hline $8: 0$ & 1.25 & 0.97 & 0.05 & $<0.001$ \\
\hline $10: 0$ & 2.73 & 2.21 & 0.12 & $<0.001$ \\
\hline $12: 0$ & 3.07 & 2.69 & 0.10 & $<0.001$ \\
\hline $14: 0$ & 10.23 & 9.95 & 0.18 & 0.12 \\
\hline $14: 1$ & 0.84 & 0.98 & 0.07 & 0.04 \\
\hline $15: 0$ & 0.84 & 0.84 & 0.02 & 0.82 \\
\hline $16: 0$ & 28.18 & 25.56 & 0.57 & $<0.001$ \\
\hline $16: 1$ & 1.34 & 1.45 & 0.10 & 0.28 \\
\hline $17: 0$ & 0.42 & 0.44 & 0.01 & 0.22 \\
\hline 18:0 & 12.17 & 12.19 & 0.53 & 0.96 \\
\hline 18:1 trans -4 & 0.03 & 0.03 & 0.01 & 0.40 \\
\hline $18: 1$ trans -5 & 0.03 & 0.03 & 0.01 & 0.61 \\
\hline $18: 1$ trans $6-8$ & 0.40 & 0.48 & 0.01 & $<0.001$ \\
\hline 18:1 trans -9 & 0.31 & 0.36 & 0.01 & $<0.001$ \\
\hline $18: 1$ trans -10 & 0.55 & 0.69 & 0.02 & $<0.001$ \\
\hline 18:1 trans -11 & 1.11 & 1.08 & 0.04 & 0.44 \\
\hline 18:1 trans -12 & 0.98 & 0.73 & 0.55 & 0.66 \\
\hline $18: 1$ cis -9 & 21.58 & 25.16 & 0.90 & $<0.001$ \\
\hline $18: 2$ cis -9, cis -12 & 3.12 & 3.59 & 0.12 & $<0.001$ \\
\hline $18: 2$ cis -9, trans -11 & 0.44 & 0.51 & 0.02 & 0.01 \\
\hline $18: 2$ trans -10, cis -12 & $<0.01$ & 0.04 & 0.01 & $<0.001$ \\
\hline $18: 3$ & 0.44 & 0.50 & 0.02 & 0.01 \\
\hline $20: 0$ & 0.09 & 0.09 & 0.01 & 0.81 \\
\hline Other & 3.03 & 3.31 & 0.05 & $<0.001$ \\
\hline \multicolumn{5}{|l|}{ Summation } \\
\hline$<\mathrm{C} 16$ & 25.68 & 23.35 & 0.60 & $<0.001$ \\
\hline C16 \& C16:1 & 29.49 & 27.03 & 0.61 & 0.001 \\
\hline$>\mathrm{C} 16$ & 44.63 & 49.20 & 1.16 & 0.001 \\
\hline \multicolumn{5}{|l|}{ Desaturase index } \\
\hline $14: 1 / 14: 0$ & 0.08 & 0.10 & 0.01 & 0.01 \\
\hline $16: 1 / 16: 0$ & 0.05 & 0.06 & 0.003 & 0.02 \\
\hline 18:1/18:0 & 1.83 & 2.20 & 0.12 & 0.01 \\
\hline$c 9, t 11$ CLA/18:1 $t 11$ & 0.41 & 0.48 & 0.03 & 0.02 \\
\hline
\end{tabular}

${ }^{1}$ Cows received a dietary fat supplement consisting of Ca-salts of palm oil fatty acids (control treatment) or Ca-salts of a mixture of conjugated linoleic acid isomers plus palm oil fatty acids (CLA treatment).

${ }^{2}$ There was no treatment $\times$ time interaction and values represent average of milk samples obtained at treatment week $2,4,8,12,16$, and 20 .

out the study (data not presented). Studies utilizing short-term abomasal infusion of trans-10, cis-12 CLA have indicated that about 10 to $25 \%$ of the infused dose of trans-10, cis-12 CLA was transferred to milk fat (Chouinard et al., 1999a, 1999b; Baumgard et al., 2001). This difference suggests that a substantial portion of the calcium salts of CLA used in the present study were metabolized in the rumen. While the transfer efficiency of rumen-protected CLA was much less than that of the abomasal infusion studies, the magnitude of reduction in milk fat is much greater than would be predicted based on the milk fat content of trans-10, cis-12 CLA observed with abomasal infusion studies (Peterson et al., 2002). This suggests that the rumen-protected CLA supplement may contain other isomers or be metabolized to other isomers that may also inhibit milk fat synthesis. This situation is similar to diet-induced milk fat depression where the amount of trans-10, cis-12 CLA found in milk does not completely explain the total milk fat reduction (Bauman et al., 2000, 2001). Nevertheless, rumen protection is still an effective delivery system for CLA, as it has been shown to cause a $100 \%$ reduction in milk fat compared with CLA in oil form (Hawley et al., 2001).

The enzyme $\Delta^{9}$-desaturase plays an essential role in the maintenance of cellular membrane fluidity through introduction of a cis-9 double bond in fatty acids (Ntambi, 1999). In mammary, $\Delta^{9}$-desaturase plays an additional critical role in the maintenance of milk fat fluidity (Kinsella, 1972). There are four pairs of fatty acids in milk fat that represent product/substrate for $\Delta^{9}$-desaturase, and their ratio in milk fat can serve as a proxy for $\Delta^{9}$-desaturase in the mammary gland (Bauman et al. 2001). These pairs are called the desaturase index and they are: $\mathrm{C} 14: 1 / \mathrm{C} 14: 0, \mathrm{C} 16: 1 / \mathrm{C} 16: 0, \mathrm{C} 18: 1 / \mathrm{C} 18: 0$, and cis-9, trans-11 CLA/trans-11 C18:1. Abomasal infusions of high doses of CLA isomer mixtures reduced the ratios in milk fat, indicating a decrease in quantity or activity of $\Delta^{9}$-desaturase (Chouinard et al., 1999a; 1999b). Baumgard et al. (2001) showed that the trans-10, cis-12 CLA reduced the desaturase index, whereas the cis-9, trans-11 isomer had no effect. Studies involving growing rodents have demonstrated that the trans-10, cis-12 isomer affected both enzyme activity and gene expression for $\Delta^{9}$-desaturase (Lee et al., 1998; Bretillon et al., 1999; Park et al., 2000). In the present study, there was no indication of a reduction in $\Delta^{9}$-desaturase based on ratios of the fatty acid pairs, and in fact there was a small but significant increase in the ratios (Table 6). This lack of reduction in the desaturase index is likely related to dosage. Whereas high doses of trans-10, cis-12 CLA (7.0 and $14.0 \mathrm{~g} / \mathrm{d}$ ) shifted desaturase index, lower doses had no effect even though milk fat yield was reduced (Baumgard et al., 2001; Peterson et al., 2002). When $\Delta^{9}$-desaturase is markedly reduced by extremely high doses of CLA, effects on lipid fluidity may impair the formation and secretion of milk fat and the turnover of cellular membranes. This could explain the apoptosis observed in some in vitro cultures when cells were incubated with high concentrations of CLA (Ip et al., 1999) and could be the basis for the decline in milk synthesis observed when lactating dairy cows are abomasally infused with extreme levels of CLA (150 g/d) (Bell and Kennelly, 2001).

Specific protein fractions and TP are also important when considering the manufacturing properties of milk. Specific milk proteins were compared between treatment groups and no significant differences were observed (Ta- 
Table 7. Milk nitrogen fractions from cows receiving rumen-protected fat supplements.

\begin{tabular}{lcrlll}
\hline & \multicolumn{2}{c}{ Treatment $^{1,2}$} & & \\
\cline { 2 - 3 } Milk variable & Control & CLA & & SEM & $P$ \\
\hline CP, ${ }^{3} \%$ & 3.32 & 3.32 & 0.11 & 0.99 \\
TP, ${ }^{4} \%$ & 3.12 & 3.12 & 0.10 & 0.98 \\
Casein, ${ }^{5 \%}$ & 2.56 & 2.53 & 0.08 & 0.71 \\
Whey protein ${ }^{6} \%$ & 0.57 & 0.59 & 0.04 & 0.46 \\
NPN $\times 6.38,{ }^{7} \%$ & 0.19 & 0.20 & 0.004 & 0.44 \\
NCN $\times 6.38,7 \%$ & 0.76 & 0.79 & 0.04 & 0.42 \\
Casein, \% of TP & 82.04 & 80.98 & 0.83 & 0.22 \\
NPN, \% of TP & 6.23 & 6.34 & 0.22 & 0.63 \\
\hline
\end{tabular}

${ }^{1}$ Cows received a dietary fat supplement consisting of Ca-salts of palm oil fatty acids (control treatment) or Ca-salts of a mixture of conjugated linoleic acid isomers plus palm oil fatty acids (CLA treatment).

${ }^{2}$ There was no treatment $\times$ time interaction and values represent average of milk samples obtained at treatment wk $2,4,8,12,16$, and 20 .

${ }^{3}$ Crude protein $(\mathrm{CP})$ equals total nitrogen $(\mathrm{TN}) \times 6.38$.

${ }^{4}$ True protein $(\mathrm{TP})$ calculated as $(\mathrm{TN}-\mathrm{NPN}) \times 6.38$.

${ }^{5}$ Casein protein calculated as $(\mathrm{TN}-\mathrm{NCN}) \times 6.38$.

${ }^{6}$ Whey protein calculated as $(\mathrm{NCN}-\mathrm{NPN}) \times 6.38$.

${ }^{7}$ Multiplied by 6.38 to allow comparison with other protein fractions.

ble 7). Thus, results suggest that the manufacturing properties related to milk proteins were unaffected by the use of CLA supplements during established lactation.

One key objective was to assess the ability of CLAsupplemented cows to replenish body fat reserves and maintain their overall well-being. Blood concentrations of glucose, BHBA, and NEFA were unaffected, although there was a trend $(P<0.08)$ for lower plasma BHBA concentrations in the CLA treated group (Table 8). We observed affects on DMI, BW or BCS (Table 4). The temporal patterns of DMI, BW and BCS were nearly identical between CLA-supplemented and control treatment groups (Figures 3 and 4). Thus, cows receiving CLA were able to replenish their body reserves in a

Table 8. Plasma metabolites of cows receiving the rumen-protected fat supplements.

\begin{tabular}{lcccc}
\hline & \multicolumn{2}{c}{ Treatment $^{1,2}$} & & \\
\cline { 2 - 3 } Variable & Control & CLA & SEM & $P$ \\
\hline Glucose, $\mathrm{mg} / \mathrm{dL}$ & 51.0 & 52.4 & 1.7 & 0.56 \\
BHBA, mg/dL & 7.1 & 6.4 & 0.3 & 0.08 \\
NEFA, $\mu \mathrm{eq} / \mathrm{L}$ & 171 & 160 & 20 & 0.70 \\
\hline
\end{tabular}

${ }^{1}$ Cows received a dietary fat supplement consisting of Ca-salts of palm oil fatty acids (control treatment) or Ca-salts of a mixture of conjugated linoleic acid isomers plus palm oil fatty acids (CLA treatment).

${ }^{2}$ There was no treatment $\times$ time interaction and values represent average of milk samples obtained at treatment week 1, 2, 3, 4, 8, 12, 16 , and 20 .

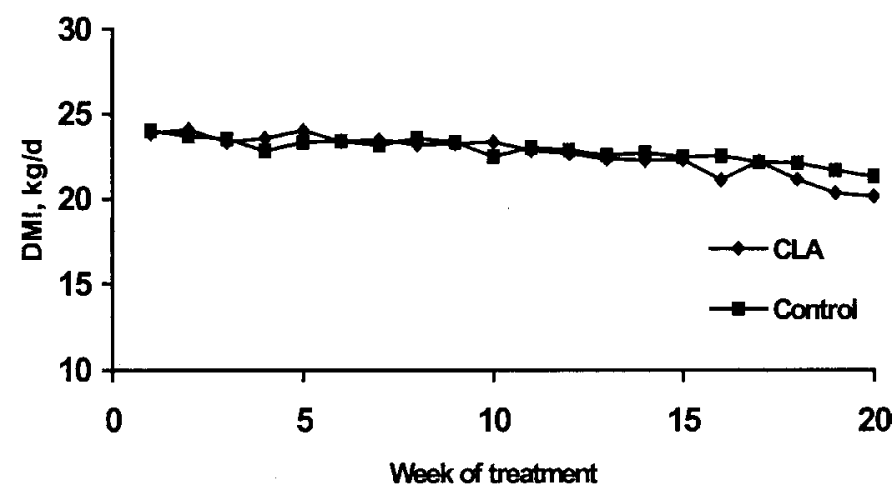

Figure 3. Temporal pattern of dry matter intake for cows fed a rumen-protected fat supplement with or without conjugated linoleic acid (CLA). Values are means, $n=12$ for control and 11 for CLA treatments; SEM averaged $0.5 \mathrm{~kg} / \mathrm{d}$.

typical manner. Body reserves are of particular importance to milk production in early lactation, and the milk yield over the first $6 \mathrm{wk}$ of the subsequent lactation was similar for the two treatment groups $(44.5 \pm 4.2 \mathrm{~kg} / \mathrm{d}$ for control and $47.1 \pm 5.4 \mathrm{~kg} / \mathrm{d}$ for CLA-supplemented groups). The ability of CLA supplemented cows to replenish body fat reserves contrasts with studies involving growing animals in which CLA supplements have been shown to reduce body fat accretion in rats (Azain et al.,

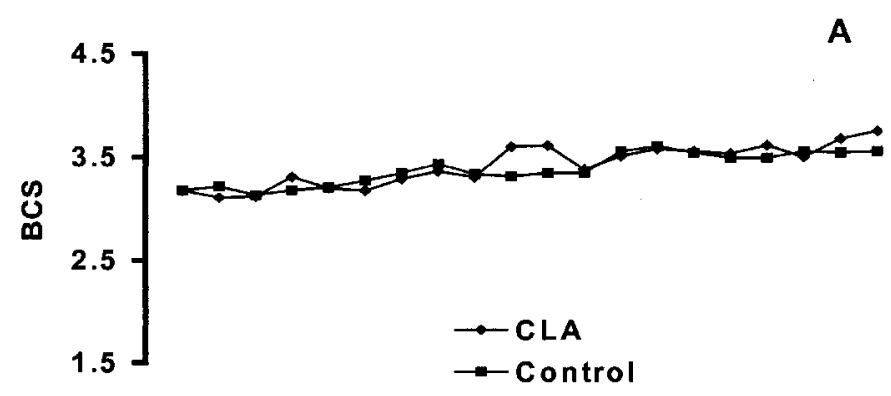

B

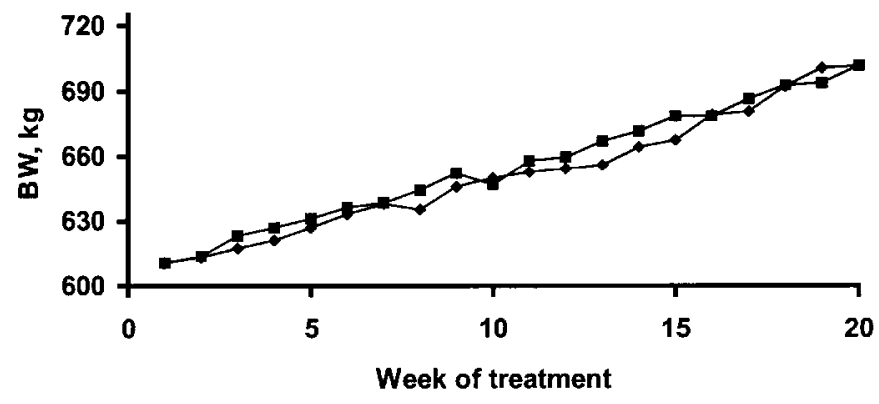

Figure 4. Temporal pattern of body condition score (A) and body weight (B) for cows fed a rumen-protected fat supplement with or without conjugated linoleic acid (CLA). Values are means, $n=12$ for control and 11 for CLA treatments; SEM averaged 0.1 for body condition score and $6 \mathrm{~kg}$ for body weight. 
Table 9. Calving records from the cows completing the 20 -wk treatment period.

\begin{tabular}{lcccc}
\hline & \multicolumn{2}{c}{ Treatment $^{1}$} & & \\
\cline { 2 - 3 } & Control & CLA & SEM & $P$ \\
\hline $\begin{array}{l}\text { Parturitions, } \mathrm{n} \\
\text { Calves born, } \mathrm{n}\end{array}$ & 12 & 11 & & \\
$\quad$ Gestation length, day & $13^{2}$ & $11^{3}$ & & \\
$\quad$ Males & 276 & 278 & 6 & 0.74 \\
$\quad$ Females & 275 & 276 & 5 & 0.86 \\
$\quad$ Birth weight, ${ }^{4} \mathrm{~kg}$ & & & & \\
$\quad$ Males & 47.8 & 51.4 & 5.2 & 0.63 \\
$\quad$ Females & 43.8 & 45.3 & 2.9 & 0.71 \\
$\quad$ Overall & 45.6 & 48.3 & 3.1 & 0.38 \\
\hline
\end{tabular}

${ }^{1}$ Cows received a dietary fat supplement consisting of Ca-salts of palm oil fatty acids (control treatment) or Ca-salts of a mixture of conjugated linoleic acid isomers plus palm oil fatty acids (CLA treatment).

${ }^{2}$ Single calf born dead; twin to a healthy female.

${ }^{3}$ Single calf born dead.

${ }^{4}$ Values do not include weights of calves born dead.

2000), mice (DeLany et al., 1999), and pigs (Dugan et al., 1997; Ostrowska et al., 1999). Baumgard et al. (2002) noted that the CLA doses used in studies with growing animals are several-fold greater than those used in lactation studies, including the present study. Consequently, the different effects on body fat may be related to dose, but could also be related to other factors such as physiological state and/or species differences.

Cows fed the CLA supplement clearly differed in energy partitioning. The $23 \%$ reduction in milk fat yield is equivalent to $2.8 \mathrm{Mcal} / \mathrm{d}$. While there were no significant treatment effects on DMI, milk yield, or BW, small differences between treatments for these variables resulted in no significant difference in net energy balance [NEB (Table 4)]. In the case of growing rodents, some studies have suggested a mechanism whereby CLA reduces body fat accretion through an increase in energy losses (DeLaney et al., 1999; West et al., 2000). This involves an increase in heat production and a reduction in efficiency of nutrient use. The present study provides no evidence that CLA adversely affecting metabolic efficiency. The lack of treatment differences in calculated NEB (Table 4) agrees with the lack of any treatment differences in BW gain and BCS (Figure 4). Nevertheless, the effect of CLA on bioenergetics will be an area of continued interest as others seek to verify and extend our results.

The present study was also the first to feed rumenprotected CLA to pregnant dairy cows, and relevant variables are presented in Table 9. Pregnancy was maintained for all animals, and no differences were observed between treatment groups for gestation length. Parturition and calf health also appeared normal, and there were no treatment effects on average birth weight. The maintenance of pregnancy was of concern due to studies that showed a high embryonic mortality and reduced hatchability of eggs from birds fed a diet supplemented with CLA (Aydin et al., 1999a, 1999b). These adverse effects are probably related to the dose of CLA ( $0.5 \%$ of the diet) and its affect on $\Delta^{9}$-desaturase, as eggs from CLA-supplemented birds had a marked reduction in lipid content of unsaturated fatty acids. Cyclopropenoid fatty acids found in some feeds (e.g. cottonseed) also inhibit $\Delta^{9}$-desaturase, and this can impair reproduction in birds and mammals (Phelps et al., 1964). Dietary supplements of unsaturated fatty acids overcame the adverse reproduction effects of cyclopropenoid fatty acids in birds and rodents (Phelps et al., 1964; Nixon et al., 1977). Recently, it was demonstrated that addition of olive oil to the diet of CLA-supplemented birds also prevented the adverse effects on reproduction (Aydin et al., 2001). Thus, the lack of an effect of CLA on pregnancy is consistent with the absence of any adverse effects on $\Delta^{9}$-desaturase as seen in milk fat values for the desaturase index ratios (Table 6). In other studies that had objectives unrelated to reproduction, there were no apparent complications in the maintenance of pregnancy or fetal development when dietary supplements of CLA were fed to rats (Chin et al., 1994) or sows (Bee, 2000; Poulos et al., 2000).

In conclusion, we have shown that supplementing rumen-protected CLA to pregnant dairy cows during established lactation causes an immediate and consistent reduction in milk fat yield while milk yield and other milk components were unaltered. Cows receiving the CLA supplement were able to replenish their body reserves much like the control group, and maintenance of pregnancy was not compromised. Reducing milk fat without altering other milk components could allow dietary supplements of CLA to be used as a valuable management tool in certain specialized situations.

\section{ACKNOWLEDGMENTS}

The support of Kevin Murphy (Bioproducts Inc.) and Rick Spratt (Agribrands Purina Canada Inc.) in implementing the study is gratefully acknowledged. The assistance of the following students and colleagues at Cornell University is also appreciated: Mary Partridge, Tom Muscato, Debbie Dwyer, David Barbano, Joanna Lynch, Dottie Ceurter, Ben Corl, Lance Baumgard, Amy Ziegler, Romona Slepetis, Matt Waldron, Mike Piepenbrink, Lisa Ruzzi, Melissa Bischoff, and Kristen Vyhnal.

\section{REFERENCES}

Association of Official Analytical Chemists, International. 2000. Official Methods of Analysis. 17th Ed. AOAC, Arlington, VA.

Aydin, R., M. W. Pariza, and M. E. Cook. 1999a. Effect of dietary conjugated linoleic acid on egg yolk fatty acids and hatchability in Japanese quail. J. Poultry Sci. 78(Suppl. 1):75. (Abstr.). 
Aydin, R., M. W. Pariza, and M. E. Cook. 1999b. Dietary conjugated linoleic acid inhibits the hatchability of pigeon eggs. J. Poultry Sci. 78(Suppl. 1):115. (Abstr.).

Aydin, R., M. W. Pariza, and M. E. Cook. 2001. Olive oil prevents the adverse effects of dietary conjugated linoleic acid on chick hatchability and egg quality. J. Nutr. 131:800-806.

Azain, M. J., D. B. Hausman, M. B. Sisk, W. P. Flatt, and D. E. Jewell. 2000. Dietary conjugated linoleic acid reduces rat adipose tissue cell size rather than cell number. J. Nutr. 130:1548-1554.

Bauman, D. E., B. A. Corl, L. H. Baumgard, and J. M. Griinari. Conjugated linoleic acid (CLA) and the dairy cow. 2001. Pages 237-266 in Recent Advances in Animal Nutrition. P.C. Garnsworthy and D. J. Cole, ed. Nottingham University Press, Nottingham, UK.

Bauman, D. E., and J. M. Griinari. 2001. Regulation and nutritional manipulation of milk fat: low-fat milk syndrome. Livestock Prod. Sci. 70:15-29.

Baumgard, L. H., B. A. Corl, D. A. Dwyer, and D. E. Bauman. 2000. Identification of the conjugated linoleic acid isomer that inhibits milk fat synthesis. Am. J. Physiol. 278:R179-R184

Baumgard, L. H., J. K. Sangster, and D. E. Bauman. 2001. Milk fat synthesis in dairy cows is progressively reduced by increasing supplemental amounts of trans-10, cis-12 conjugated linoleic acid (CLA). J. Nutr. 131:1764-1769.

Baumgard, L. H., B. A. Corl, D. A. Dwyer, and D. E. Bauman. 2002. Effects of conjugated linoleic acids (CLA) on tissue response to homeostatic signals and plasma variables associated with lipid metabolism in lactating dairy cows. J. Anim. Sci. (accepted).

Bee, G. 2000. Dietary conjugated linoleic acids alter adipose tissue and milk lipids of pregnant and lactating sows. J. Nutr. 130:2292-2298.

Bell, J. A., and J. J. Kennelly. 2001. Synthetic conjugated linoleic acid may cause mammary involution in dairy cows. J. Dairy Sci. 84(Suppl. 1):8. (Abstr.).

Bernal-Santos, G., J. W. Perfield II, T. R. Overton, and D. E. Bauman. 2001. Production responses of dairy cows to dietary supplementation with conjugated linoleic acid (CLA) during the transition period and early lactation. J. Dairy Sci. 84(Suppl. 1):82. (Abstr.).

Bretillon, L., J. M. Chardigny, S. Grégoire, O. Berdeaux, and J. L. Sébédio. 1999. Effects of conjugated linoleic acid isomers on the hepatic microsomal desaturation activities in vitro. Lipids 34:965-969.

Chin, S. F., J. M. Storkson, K. J. Albright, M. E. Cook, and M. W. Pariza. 1994. Conjugated linoleic acid is a growth factor for rats as shown by enhanced weight gain and improved feed efficiency. J. Nutr. 124:2344-2349.

Chouinard, P. Y., L. Corneau, D. M. Barbano, L. E. Metzger, and D. E. Bauman. 1999a. Conjugated linoleic acids alter milk fatty acid composition and inhibit milk fat secretion in dairy cows. J. Nutr. 129:1579-1584.

Chouinard, P. Y., L. Corneau, A. Sæbø, and D. E. Bauman. 1999b. Milk yield and composition during abomasal infusion of conjugated linoleic acids in dairy cows. J. Dairy Sci. 82:2737-2745.

Christie, W. W. 1982. A simple procedure for rapid transmethylation of glycerolipids and cholesteryl esters. J. Lipid Res. 23:1072-1075.

Christie, W. W. 1989. Page 68 in Gas Chromatography and Lipids: A Practical Guide. The Oily Press, Ayr, Scotland.

DeLany, J. P., F. Blohm, A. A. Truett, J. A. Scimeca, and D. B. West. 1999. Conjugated linoleic acid rapidly reduces body fat content in mice without affecting energy intake. Am. J. Physiol. 276:R1172-R1179.

Dugan, M. E. R., J. L. Aalhus, A. L. Schaefer, and J. K. G. Kranmer. 1997. The effect of conjugated linoleic acid on fat to lean repartitioning and feed conversion in pigs. Can. J. Anim. Sci. 77:723-725.

Fox, D. G., C. J. Sniffen, J. D. O'Connor, J. B. Russell, and P. J. Van Soest. 1992. A net carbohydrate and protein system for evaluating cattle diets: III. Cattle requirements and diet adequacy. J. Anim. Sci. 70:3578-3596.

Giesy, J. G., M. A. McGuire, B. Shafii, and T. W. Hanson. 1999. Effects of Calcium salts of Conjugated linoleic acid (CLA) on milk production and energy balance of early lactation Holsteins. J. Dairy Sci. 82(Suppl. 1):83. (Abstr.).
Griinari, J. M., and D. E. Bauman. Biosynthesis of conjugated linoleic acid and its incorporation into meat and milk in ruminants. Pages 180-200 in Advances in Conjugated Linoleic Acid Research. Vol. I. M. P. Yurawecz, M. M. Mossoba, J. K. G. Kramer, M. W. Pariza, and G. J. Nelson, ed. AOCS Press, Champaign, IL.

Hara, A., and N. S. Radin. 1978. Lipid extraction of tissues with a low-toxicity solvent. Anal. Biochem. 90:420-426.

Harrell, R. J., O. Phillips, D. L. Jerome, R. D. Boyd, D. A. Dwyer, and D. E. Bauman. 2000. Effects of conjugated linoleic acid on milk composition and baby pig growth in lactating sows. J. Anim. Sci. 77(Suppl. 1):137-138. (Abstr.).

Hawley, M. M., M. A. McGuire, T. W. Hanson, and A. F. Kertz. 2001. Conjugated linoleic acid (CLA) must be protected from rumen hydrogenation for the greatest impact on milk composition. J. Dairy Sci. 84(Suppl. 1):355. (Abstr.).

Ip, M. M., P. A. Masso-Welch, S. F. Shoemaker, W. K. Shea-Eaton, and C. Ip. 1999. Conjugated linoleic acid inhibits proliferation and induces apoptosis of normal rat mammary epithelial cells in primary culture. Exp. Cell Res. 250:22-34.

Kinsella, J. E. 1972. Stearyl-CoA as a precursor of oleic acid and glycerolipids in mammary microsomes from lactating bovine: possible regulatory step in milk triglyceride synthesis. Lipids 7:349-355.

Lee, K. N., M. W. Pariza, J. M. Ntambi. 1998. Conjugated linoleic acid decreases hepatic stearoyl-CoA desaturase mRNA expression. Biochem. Biophys. Res. Commun. 248:817-821.

Loor, J. J., and J. H. Herbein. 1998. Exogenous conjugated linoleic acid isomers reduce bovine milk fat concentration and yield by inhibiting de novo fatty acid synthesis. J. Nutr. 128:2411-2419.

Masters, N., M. A. McGuire, and M. K. McGuire. 1999. Conjugated linoleic acid supplementation and milk fat content in humans. FASEB J. 13:A697. (Abstr.).

Medeiros, S. R., D. E. Oliveira, L. J. M. Aroeira, M. A. McGuire, D. E. Bauman, and D. P. D. Lanna. 2000. The effect of long term supplementation of conjugated linoleic acid (CLA) to dairy cows grazing tropical pasture. J. Dairy Sci. 83(Suppl. 1):169. (Abstr.).

National Research Council. 2001. Nutrient Requirements of Dairy Cattle, 7th rev. ed. National Academy of Sciences, Washington, DC.

Nixon, J. E., T. A. Eisele, J. D. Hendricks, and R. O. Sinnhuber. 1977. Reproduction and lipid composition of rats fed cyclopropene fatty acids. J. Nutr. 107:574-583.

Ntambi, J. M. 1999. Regulation of stearoyl-CoA desaturase by polyunsaturated fatty acids and cholesterol. J. Lipid Res. 40:1549-1558.

Ostrowska, E., M. Muralitharan, R. F. Cross, D. E. Bauman, and F. R. Dunshea. 1999. Dietary conjugated linoleic acids increase lean tissue and decrease fat deposition in growing pigs. J. Nutr. 129:2037-2042.

Park, Y., J. M. Storkson, J. M. Ntambi, M. E. Cook, C. J. Sih, and M. W. Pariza. 2000. Inhibition of hepatic stearoyl-CoA desaturase activity by trans-10, cis-12 conjugated linoleic acid and its derivatives. Biochim. Biophys. Acta 1486:285-292.

Peterson, D. G., L. H. Baumgard, and D. E. Bauman. 2002. Short communication: Milk fat response to low doses of trans-10, cis-12 conjugated linoleic acid (CLA). J. Dairy Sci. (accepted).

Phelps, R. A., F. S. Shenstone, A. R. Kemmerer, and R. J. Evans. 1964. A review of cyclopropenoid compounds: biological effects of some derivatives. Poult. Sci. 44:358-394.

Poulos, S. P., M. J. Azain, and G. J. Hausman. 2000. In utero dietary conjugated linoleic acid (CLA) alters body composition and growth rate in new-born pigs. J. Anim. Sci. 78(Suppl. 1):137. (Abstr.).

SAS User's Guide: Statistics, Version 6.12 Edition. 1998. SAS Inst., Inc., Cary, NC.

West, D. B., F. Y. Blohm, A. A. Truett, and J. P. DeLany. 2000. Conjugated linoleic acid persistently increases total energy expenditure in AKR/J mice without increasing uncoupling protein gene expression. J. Nutr. 130:2471-2477.

Wildman, E. E., G. M. Jones, P. E. Wagner, R. L. Boman, H. F. Trout, and T. N. Lesch. 1982. A dairy cow body condition scoring system and its relationship to selected production variables in high producing Holstein dairy cattle. J. Dairy Sci. 65:495-501. 